\title{
Self-Concept of Kindergarten Teachers about Implementation of Classroom Action Research
}

\author{
Sri Hartati \\ Department of Early Childhood Education \\ Faculty of Education, Universitas Negeri Padang \\ Padang, Indonesia \\ sri.pgpaudfipunp@gmail.com
}

\begin{abstract}
The purpose of this research is to identify the self-concept of kindergarten teachers about Classroom Action Research. The method of this research is descriptive which use quantitative. Approach data is collected through questionnaire, then analysed by using formula $P=F / N$. Result of this study showed that the self-concept of kindergarten teachers in North Padang subdistrict who got education and training about classroom action its still very low. Research still belong to low category within comprehension about how to design, implementation, and arrange the Classroom Action Research report. Based on result of this research, propositioned for related institute or organization to give education and training about measure class research so that kindergarten teachers have knowledge and comprehension more deeply, so they can implement the Classroom Action Research in the future.
\end{abstract}

Keywords-classroom; action research, self-concept, kindergarten teacher.

\section{INTRODUCTION}

\section{A. Situation Analysis}

The teachers are an important and major subsystems in improving the quality of education. In the hands of the teacher; learning outcomes that one of indicator of the quality of education more determined. Without a professional teacher, it's hard to an educational system can achieve optimal results as expected. Hence, the main prerequisites that must be met for the learning process that ensures the optimization of learning outcomes is the availability of teachers with qualifications and competencies are able to meet the demands of his job.

The best of quality learning can only be achieved if teachers have four this competencies, namely: 1) Pedagogical competence. 2) Personal competence, 3) Social competence, and 4) Professional competence.

Mastery of these competencies to be a prerequisite for a professional teacher in present and future. Competence important that now a day be a target to improve the teacher's quality for last few years is the operation of Classroom Action Research. It is expected to implement of Classroom Action Research, the weakness that occur in the learning process can be identified and detected, then it could be look for the right solution. The Classroom Action Research through which seeks to examine various phenomena that occur in the classroom, teachers are able to improve the quality of the learning process. Darmansyah [1] Classroom Action Research is an effort to improve the quality of learning is done through indepth understanding of teachers to the problems that occur in learning.

Through Classrom Action Research teachers can examine their own practices are implemented in the classroom learning, whether viewed from the interaction of students in the learning process and results are reflective. Classroom Action Research can be implemented integrated with learning activities in class everyday without disturbing the main tasks of teachers. In practice, teachers who are conducting Classroom Action Research means researching their own activities, their own class with their students involve themselves. Opportunities like this allows the teachers to reflect on the problems they face in the classroom everyday and find the best solution for performance improvement of children's learning outcomes.

Based on the observation by the researchers, particularly in institution of kindergarten, the implementation of Classrom Action Research has not been accomplished in accordance with expectations. There are still many teachers who have not been able to implement The Classroom Action Research. It caused by several possibilities, such; knowledge and understanding in Classroom Action Research, the ability to identify problems, formulate problems and to find appropriate solutions to overcome these problems is low. It is also caused because the teachers do not understand about the proper method to solve the problem, using media that isn't relevant and appropriate approach to the development aspects will be achieved add to the list of reasons to description why the teacher's self-concept is very low.

Based on the above phenomenon, the researchers are interested in doing a study entitled "Kindergarten Teacher's Self-Concept about Implementation of Classroom Action Research in North Padang Subdistrict".

Atwater [2] suggested that self-concept is basically implies an overall sense of self that includes the perception of self, feelings, beliefs and values that are associated with his-self. Furthermore, he stated that in general the self-concept identificated through "body image" is the awareness of the body (subjective self), that is how people see themselves, "ideal self" is how the ideals and values about his-self and social self is how others see themselves 
Through this research can unfold the self-concept owned by teachers on the implementation of Classroom Action Research that has been done and through this study, the researchers hopes thats that the results of this study can be a reference, especially in department of Early Childhood Education where the researchers being as one of the lecturer felt responsible to improve the quality of teachers, especially in the implementation of Class Action Research in kindergarten.

This study aims to find out the teacher's self-concept and perception of kindergarten in North Padang subdistrict, Padang City.

\section{METHODOLOGY OF RESEARCH}

This study is a descriptive study by using Quantitative approach. Abdurrahman [3] suggests that descriptive research is a something studies that intend to conduct inspections and measurements are specific to certain symptoms.

Based on the above opinion can be concluded that descriptive research is a research Classroom Action Researchried out systematically and were taken from the actual reality. This research was conducted in kindergarten located in the subdistrict of North Padang, Padang City. The population in this study were all kindergarten teachers who were in the subdistrict of North Padang. While the sample in this study conducted by Convienence Sampling technique.

According Sugiyono [4] purposive sampling is a technique of taking a data source with a certain consideration. This judgment is based on the assumption that informants considered most knowledgeable about the Influence the kindergarten teacher's Perception and Self-Concept to the understanding of Classroom Action Research so making it easier for the researchers to explore the situation under study.

Pre-survey obtained the number of kindergartens in the subdistrict of North Padang more \pm 60 Kindergatens. Samples taken are the teachers who have a relevant educational background, which as degree's holder in early childhood education in the subdistrict of North Padang, Padang.

The tools used to collect the data in the theacher's selfconcept studies about Classroom Action Research formulated in the form of a large-scale questionnaire prepared by grating that has been formulated. The steps taken in developing the data collection tool covering the activities of designing instruments that can reveal data that has been determined. Phase traversed in preparing this instrument are: a) Determining aspects of the study variables; b) formulate a questionnaire item; c) Inspection item questionnaire by the research team.

This questionnaire consists of 50 items and has four alternative answers, ie ranging from Strongly Agree (SA) showed ahigh self-concept, up to Strongly Disagree (SD) showed the concept itself is very low. The data collection technique is very important to do the research. The research was conducted using a questionnaire. Questionnaires were used and then distributed to teachers in kindergarten in the subdistrict in North Padang, Padang City.

After the data is collected, the data is processed or analyzed using a percentage formula. Data analysis technique used was proposed by A. Muri [5] as follows:

$100 \%$

$$
\mathbf{P}=\mathbf{f} / \mathbf{N}
$$

Information :

$\mathrm{P}=$ Percentage

$\mathrm{f}=$ Frequency

$\mathrm{N}=$ Number of Respondents

\section{RESULTS AND DISCUSSION}

The research findings related to the image of selfconcept kindergarten's teachers who have received training in the subdistrict in Padang Utara are presented in the table. Item of instruments on the self-concept proposed the choice of answers strongly agree and agree are negative, if the informant answered strongly agree or agree it showe that the concept of self-esteem is low and unfavorable, on the contrary, if the informant showed very less agree or disagree indicating a high or good self-concept.

TABLE 1. OVERVIEWS OF THE TEACHER SELF CONCEPT WHO ALREADY GETTING CLASS ACTION REASEARCH TRAINING ON CAR'S CONCEPTS, AND PREPARATION OF CLASS ACTION RESEARCH'S PLANNING

\begin{tabular}{|c|c|c|c|c|c|}
\hline NO & $\mathbf{\% ~ S R ~}$ & $\mathbf{\% ~ R}$ & $\mathbf{\%} \mathbf{C}$ & $\mathbf{\%}$ T & $\mathbf{\% ~ S T ~}$ \\
\hline 2 & $28.57 \%$ & $42.86 \%$ & $28.57 \%$ & $0 \%$ & $0 \%$ \\
\hline 38 & $7.14 \%$ & $50 \%$ & $7.14 \%$ & $28,58 \%$ & $7,14 \%$ \\
\hline 39 & $0 \%$ & $21.43 \%$ & $21.43 \%$ & $42.85 \%$ & $14.29 \%$ \\
\hline 40 & $0 \%$ & $21.42 \%$ & $50 \%$ & $14.28 \%$ & $14.28 \%$ \\
\hline 42 & $0 \%$ & $21.43 \%$ & $42.85 \%$ & $35.72 \%$ & $0 \%$ \\
\hline 43 & $0 \%$ & $35.72 \%$ & $28.57 \%$ & $21.42 \%$ & $14.29 \%$ \\
\hline$\Sigma$ & $\mathbf{5 , 9 5} \%$ & $\mathbf{3 2 , 1 5 \%}$ & $\mathbf{2 9 , 7 6 \%}$ & $\mathbf{2 3 , 8 \%}$ & $\mathbf{8 , 3 4} \%$ \\
\hline
\end{tabular}

According to the table 1 shows that the average of teacher's self-concept who have received education and training of Classroom Actiom Research. The Classroom Action Reseach's planning arrangement shows the results $=$ $32.15 \%$, it means that teachers have a low self-concepting. That is a small fraction of teachers who have received training of Classroom Action Research who have high self-concept, but most teachers have received training have lower selfconcept, as seen in the table showing the results are $38.10 \%$ $(\mathrm{SR}+\mathrm{R})$. 
TABLE 2. OVERVIEWS OF SELF CONCEPT OF TEACHERS WHO GETTING CLASS ACTION RESEARCH TRAINING ON PTK IMPLEMENTATION

\begin{tabular}{|c|c|c|c|c|c|}
\hline NO & $\mathbf{\% ~ S R ~}$ & $\mathbf{\%} \mathbf{R}$ & $\mathbf{\%} \mathbf{C}$ & $\mathbf{\% ~ T}$ & $\mathbf{\% ~ S T ~}$ \\
\hline 41 & $0 \%$ & $21,43 \%$ & $35,71 \%$ & $28.57 \%$ & $14.29 \%$ \\
\hline 45 & $7.14 \%$ & $28.57 \%$ & $57.15 \%$ & $7.14 \%$ & $0 \%$ \\
\hline 46 & $7.14 \%$ & $35.72 \%$ & $35.72 \%$ & $21.42 \%$ & $0 \%$ \\
\hline 48 & $7.15 \%$ & $42.85 \%$ & $42.85 \%$ & $7.15 \%$ & $0 \%$ \\
\hline$\Sigma$ & $\mathbf{5 . 3 6} \%$ & $\mathbf{3 2 , 1 4 \%}$ & $\mathbf{4 2 , 8 6 \%}$ & $\mathbf{1 6 , 0 7 \%}$ & $\mathbf{3 . 5 7 \%}$ \\
\hline
\end{tabular}

Based on Table 2 shows that the average of the teacher's self-concept who have not received education and training on Classroom Action Research's planning showed the result $19.64 \%$, means that teachers have low self-concept.

TABLE 3. OVERVIEWS OF SELF CONCEPT ON PREPARATION OF 1 . CLASS ACTION RESEARCH REPORTS FOR KINDERGARTEN TEACHERS WHO HAVE GAINED CAR'S TRAINING IN NORT PADANG SUBDISTRICT

\begin{tabular}{|c|c|c|c|c|c||}
\hline NO & SR & R & C & T & ST \\
\hline 44 & $0 \%$ & $42.85 \%$ & $35.72 \%$ & $14.29 \%$ & $7.14 \%$ \\
\hline 47 & $0 \%$ & $42.85 \%$ & $50 \%$ & $7.15 \%$ & $0 \%$ \\
\hline 49 & $0 \%$ & $42.86 \%$ & $42.86 \%$ & $14.28 \%$ & $0 \%$ \\
\hline 50 & $7.14 \%$ & $35.72 \%$ & $42.85 \%$ & $14.29 \%$ & $0 \%$ \\
\hline$\Sigma$ & $\mathbf{1 . 7 9} \%$ & $\mathbf{4 1 . 0 7 \%}$ & $\mathbf{4 2 . 8 5 \%}$ & $\mathbf{1 2 . 5 \%}$ & $\mathbf{1 . 7 9 \%}$ \\
\hline \multicolumn{7}{|l}{} \\
\hline
\end{tabular}

Table 3 shows that the 14:29\% Kindergarten teachers have received training have self-concepts to the preparation for arranging the report of Classroom Action Research mean is still very high. However $42.86 \%$ kindergarten's teachers who have received the training has a low self-concept. The remainder (42.85) is still undecided in the preparation of the report.

an overview of the concept of self kindergarten teacher training already getting classroom action research its findings show that the majority of kindergarten teachers who had received education and training of classroom action research has the concept in the low category or less so towards the understanding of classroom action research, in planning a classroom action research, the implementation of Classroom action research, the preparation of the classroom action research. This situation is certainly quite disturbing, considering they are the teachers who have been trained are expected to implement the classroom action research as an attempt to overcome the problem of learning that occurs in the classroom.

Conditions of self concept they have to be very influential in his behavior in everyday life [6] including when implementing the learning in each class, this situation would also be an effect on their motivation in seeking a solution to solve the problem learning that it faces. This will certainly reduce the quality of learning. The matter right now is why there are many teachers who have poor/low self-concept?.

If traced from the dominant factors that influence the formation and development of self-concept, consisting of: 1) the factors of parents, peers, 3) community, 4) Association, 5) as a result and 6) motivation. In connection with the above opinion that self-concept of teachers is influenced by several factors that have been mentioned above. Of a number of factors that can not be identified is the most dominant factor. Given a teacher is an adult certainly the dominant factor is derived from themselves the association, motivation.

Be aware that the factors of self-concept can be changed. Changes occur in adults is the dominant peer and the environment, including the work environment, can also go through the process of learning and intensive training.

\section{CONCLUSION}

The results showed that the self-concept of kindergarten teachers in north padang subdistrict who have received education and training on action research is still relatively low, it is seen still many teachers still do not understand how to planning, implementation and preparation classroom action research report itself so that teachers are not able to implement the classroom action research in the field.

\section{References}

[1] Darmansyah. 2009. Penelitian Tindakan Kelas. Padang: Sukabina Press.

[2] Atwater, E (1983). Psychologi of Adjustment : personal Growhth In A Changing World. Prentice-Hall

[3] Abdurrahman, Fthoni. 2006. Manajemen Sumber Daya Manusia. Jakart: PT Rineka Cipta

[4] Sugiyono. 2007. Metode Penelitian Pendidikan. Bandung: Alfabeta.

[5] Muri Yusuf. 2014. Metode Penelitian Kuantitatif, Kualitatif dan Penelitian Jakarta: Gabungan.Prenada media Group.

[6] Hurlock, Elizabeth.B (2000). Psikologi Perkembangan: Suatu Pendekatan Sepanjang Rentang Kehidupan, Terjemah.( edisi kelima). Jakarta Erlangga 